\title{
The Effect of Principals Competencies on Teachers' Performance of Public Schools in Makassar City
}

\author{
Salmah $^{1, *}$, Arifin Ahmad ${ }^{1}$, Andi Muhammad Idkham ${ }^{2}$ \\ ${ }^{1}$ Department of Education, Universitas Negeri Makassar, Indonesia \\ ${ }^{2}$ Department of Engineering, Universitas Negeri Makassar, Indonesia
}

Received August 19, 2020; Revised November 13, 2020; Accepted November 29, 2020

\begin{abstract}
Cite This Paper in the following Citation Styles
(a): [1] Salmah, Arifin Ahmad, Andi Muhammad Idkham, "The Effect of Principals Competencies on Teachers' Performance of Public Schools in Makassar City," Universal Journal of Educational Research, Vol. 8, No. 12A, pp. 7825-7832, 2020. DOI: 10.13189/ujer.2020.082571.
\end{abstract}

(b): Salmah, Arifin Ahmad, Andi Muhammad Idkham (2020). The Effect of Principals Competencies on Teachers' Performance of Public Schools in Makassar City. Universal Journal of Educational Research, 8(12A), 7825-7832. DOI: 10.13189/ujer.2020.082571.

Copyright $\odot 2020$ by authors, all rights reserved. Authors agree that this article remains permanently open access under the terms of the Creative Commons Attribution License 4.0 International License

\begin{abstract}
The competence of the principal influences the performance of teachers in carrying out his responsibilities as a significant component in achieving educational success. Thus, the Principal should empower teachers so that they can improve their performance. This research is a correlational study which aims to determine whether there is a principal's competence on the performance of teachers in Junior High School (SMP) of the City of Makassar. The exogenous variable in this study is the competence of the Principal, while the endogenous variable is the performance of the Teacher. The population in this study was all teachers of Junior High School of the City of Makassar. At the same time, the sample was teachers of SMP Negeri 4 Makassar, teachers of SMP Negeri 6 Makassar, teachers of SMP Negeri 11 Makassar, teachers of SMP Negeri 7 Makassar, teachers of SMP Negeri 24 Makassar, and teachers of SMP Negeri 31. Makassar, with 25 teachers each school. The research data were obtained by distributing questionnaires in the form of positive and negative statement items. The data analysis technique is simple regression analysis. Based on the results of the first hypothesis test, it is obtained that $\mathrm{P}=$ 0.000 is smaller than $\alpha=0.05$. It can be concluded that there is a positive and significant influence between the competencies of school principals on the teachers' performance of Junior High School of the City of Makassar. The competence of the Principal provides a positive reflection on teachers. The higher the level of competence the Principal has, the higher the performance of the Teachers.
\end{abstract}

Keywords Principals' Competencies, Teachers' Performance, Public Schools

\section{Introduction}

One of the managerial functions performed by the Principal is the supervisory function or also known as the control function. Supervisory activities should be carried out by the Principal because it is one of the management functions and processes that must be implemented in a real way in schools. Following its essence, the supervisory activities carried out by the Principal are activities to identify what the expected results are in the plan as well as irregularities that occur in the implementation of a school program. It appears here that there are operational activities that are contained in the essence of the supervision; namely, there are efforts to improve and improve the performance of teachers. In carrying out his duties and responsibilities as an educational leader, a school principal coordinates, supervises, directs and assesses various school activities that are being programmed. Of course, it will involve teachers and educational staff.

Teachers are an essential component of education in determining the success of education. It is because teachers have multiple roles in the learning process, a teacher who not only transfers knowledge but also as a mentor who encourages students to develop alternatives in 
learning. It is just that in the process, teachers often encounter certain obstacles; for example, related to the Teacher's performance.

Teachers are required to have a performance that can provide and realize the hopes and desires of all parties, especially the general public who have trusted schools and teachers in fostering these students. In achieving good quality education, it is strongly influenced by the performance of teachers in carrying out their duties so that the performance of teachers is an essential requirement for achieving educational success. Performance problems are under the spotlight of various parties; students or parents of students felt the performance of teachers. Problems that we often hear about the low quality of educational outcomes produced by educational institutions are a reflection of the low performance produced by teachers in the process of implementing student education, both in quality and in quantity.

Based on the narrative of the Acting Head of the Makassar City Education Office, Rahman Bando, Makassar is the city with the lowest quality of education in South Sulawesi [1]. It is not because the students' abilities are low. However, this is because education services, in general, are classified as being at the bottom. These services are positively related to the performance of teachers or employees at the school. The excellent performance of teachers will create the optimal quality of human resources where expertise, emotional maturity, and morality are significant factors that teachers must have [2]. With excellent performance, professional teachers are born.

Professional teachers can carry out professionalism continuously, such as self-evaluation, self-motivation, self-discipline, and self-development [3]. All that cannot be separated from the role of a leader, namely the School Principal. The low performance of teachers is very dependent on external factors, one of which is the competence of school principals [2]. The Principal's competence dramatically influences the performance of Teachers because their main task is to provide direction, supervision, and improve the performance of Teachers [4]. It is related to the empowerment of the potential possessed by teachers. Empowerment of teaching staff is needed to optimize the performance of educational institutions. According to [5], the balance between the needs of teachers and the interests and abilities of these educational institutions can be a balance that supports the optimization of teacher performance. If synergy can be adequately established in this process, then the functions of the school as an educational institution along with all school equipment can be said to be in the right track and performance.

In achieving excellent teaching performance, it is necessary to have the competency of the Principal, who is possessed. According to the Republic of Indonesia Regulation No. 13 of 2007, the Principal must have several kinds of competences, such as personality, managerial, entrepreneurial, supervisory and social competencies. Behaviours with integrity show this competence by showing honesty, fairness and discipline, and being able to make mature programs so that learning objectives can be appropriately implemented [6].

Based on these descriptions, researchers are interested in researching the effect of competence on the performance of Public school of City of Makassar Teachers. The problem formulations in this study, is there an effect of the teachers' competence of performance in a public school in Makassar City?

\section{Literature Review}

Competence is a set of fully responsible intelligence actions that an individual must have as a condition to be considered compatible in carrying out tasks in a certain field of work [7]. Competence can also be said to be a condition that describes a person's ability or quality which is manifested in the form of rational behavior in accordance with the expected conditions and goals required according to the applicable legal provisions. As a consequence of the definition of competency, the meaning of competence refers to a person's ability to fulfill the requirements of his current or future role. Thus, competence can also predict future performance because competence is a sustainable characteristic that generally cannot be lost.

The role of competence in schools really supports the running of a good education system. As a leader, the principal is required to be able to mobilize all existing resources in a school so that they can be maximally utilized to achieve predetermined educational goals. Therefore, the principal is expected to have competency. Adequate reasoning abilities drive competence. Where the minimum abilities required by a principal are 1) able to think and control the school organization or work team they lead, 2) able to motivate, be enthusiastic, honest, disciplined, and have integrity, 3) be able to formulate policies and understand the people they lead [8]. If this reasoning ability is possessed, the Principal will be the key to moving the educational goals effectively and efficiently [6].

To drive educational goals, of course, the Principal still has to meet competency standards related to his shrewdness in organizing the people he leads. The competence of the Principal in question is the competence that refers to the standards contained in the Minister of National Education Regulation No. 13 of 2007. These competencies consist of 1) personality competence, 2) managerial, 3) entrepreneurship, 4) supervision and 5) social. Essential competencies in question can be seen in table 1. 
Table 1. Principal competence

\begin{tabular}{|c|c|}
\hline Competency & Competency Indicator \\
\hline Personality & $\begin{array}{l}\text { Have noble character, develop a culture and tradition of noble morals, and be a role model of noble morals for } \\
\text { the community in schools/madrasah } \\
\text { Have personal integrity as a leader } \\
\text { Have a strong desire for self-development as a school/madrasah principal } \\
\text { Be open in carrying out basic tasks and functions } \\
\text { Self-control in facing problems at work as a school/madrasah principal } \\
\text { Have talent and interest in the position of education leader. }\end{array}$ \\
\hline Managerial & $\begin{array}{l}\text { Prepare school/madrasah plans for various planning levels } \\
\text { Developing school/madrasah organizations as needed. } \\
\text { Lead schools/madrasah in the context of optimizing the use of school/madrasah resources } \\
\text { Managing change and development of schools/madrasah towards active learning organizations. } \\
\text { Creating a culture and school/madrasah climate that is conducive and innovative for the learning of students. } \\
\text { Managing teachers and staff in order to optimize human resource utilization. } \\
\text { Manage school/madrasah facilities and infrastructure in the context of efficient utilization. } \\
\text { Manage school/madrasah and community relationships in order to seek support for ideas, learning resources, } \\
\text { and school/madrasah funding. } \\
\text { Manage students in the context of admitting new students and placing and developing the capacity of students. } \\
\text { Manage curriculum development and learning activities following the direction and objectives of national } \\
\text { education. } \\
\text { Manage school/madrasah finances by the principles of accountable, transparent and efficient management. } \\
\text { Manage the administration of schools/madrasah in supporting the achievement of school/madrasah goals. } \\
\text { - Managing individual school/madrasah service units to support student learning and activities in } \\
\text { schools/madrasahs. } \\
\text { - Manage the school/madrasah information system to support programming and decision making. } \\
\text { Take advantage of advances in information technology for improving learning and school/madrasah } \\
\text { management. } \\
\text { Monitoring, evaluating and reporting the implementation of school/madrasah program activities with } \\
\text { appropriate procedures, and planning for follow-up. }\end{array}$ \\
\hline Entrepreneur & $\begin{array}{l}\text { Creating innovations that are useful for the development of schools/madrasah } \\
\text { Work hard to achieve the success of schools/madrasahs as active learning organizations } \\
\text { Have a strong motivation to succeed in carrying out their primary duties and functions as a school/madrasah } \\
\text { leader } \\
\text { Never give up and always look for the best solutions in facing the obstacles faced by schools/madrasahs. } \\
\text { Have an entrepreneurial instinct in managing school/madrasah production/service activities as a learning } \\
\text { resource for students. }\end{array}$ \\
\hline Supervision & $\begin{array}{l}\text { Planning an academic supervision program for teachers in order to increase teacher professionalism. } \\
\text { Carry out academic supervision in order to improve teachers by using appropriate approaches and supervision } \\
\text { techniques. } \\
\text { Follow up on the results of academic supervision of teachers in order to increase teacher professionalism. }\end{array}$ \\
\hline Social & $\begin{array}{l}\text { Cooperate with other parties for the benefit of schools/madrasahs. } \\
\text { Participate in community social activities. } \\
\text { Have social sensitivity towards other people or groups. }\end{array}$ \\
\hline
\end{tabular}

Personality is a fundamental psychological aspect that describes the identity of the principal. This personality shows the internal side of the principal, while the managerial aspect relates to the external side. Good managerial skills will support school growth and development. On the other hand, the entrepreneurial aspect will be the supporting affection of the school principal in bringing about innovation in schools. External managerial activities in general, however, the principal is also required to supervise various academic programs in schools and create social attitudes by involving various existing human resources.

The five aspects of the principal's competence are arranged into several items. These items include, such as being open to suggestions from teachers and employees at the schools I lead, I understand ways to lead school members to achieve the vision, mission and goals of the school, I have the will and passion to achieve success. In carrying out its function as a school/madrasah leader, I understand the theory and practice of performance management supervision and I make adjustments to school/madrasah programs and activities to meet the needs of the community around the school. Items such as the one above are used by researchers in constructing an assessment framework of educator performance. Based on this description, it can also be concluded that the current principal is very concerned and selective in his appointment. With the presence of this competency, it is hoped that it can improve the professionalism of the principal in managing his school so as to produce a quality school.

From research that still requires a strong evidence base, the competence of school principals can affect the performance of educators [9]. According to [7] states that 
performance is a person's success in carrying out a job, performance is the performance of someone who is shown in his appearance, deeds, and work performance [8]. Performance is measured by looking at the aspects of work performance, responsibility, obedience, honesty, and cooperation. Meanwhile, the performance of Teachers can be interpreted as a display of Teacher's work performance shown or the results achieved by Teachers on the implementation of professional and functional tasks in learning that have been determined at a particular period [9]. On the other hand, [10] explains that the performance of teachers is an effort made by a teacher in teaching and learning activities to improve the learning outcomes of their students. Based on this definition, it can be understood that the performance of teachers is the result obtained by teachers from their success in learning which is shown in appearance, actions and achievements as a form of work accumulation within a specified period.

Teachers' performance is the spearhead for the success of education [11]. The term teacher performance indicates a situation in which teachers in a school are doing things related to the task of educating and teaching in schools. Teacher performance is also related to the task of planning, managing learning, and assessing student learning outcomes. As planners, teachers must be able to design learning according to conditions in the field, as managers, namely to create a conducive learning climate so that students can learn well. Teachers, as evaluators, must be able to carry out assessment processes and student learning outcomes. The quality of the performance of teachers will significantly determine the quality of educational outcomes because teachers are the ones who have the most direct contact with students in the educational process. Therefore, it is essential to pay attention to performance factors. According to [12], some factors affect performance, namely 1) effectiveness and efficiency, 2) authority and responsibility, 3) discipline and 4) initiative and creativity.

First, effectiveness is a measure shown by the fact that the person's goals can be achieved according to the planned needs, while efficiency is related to the amount spent on achieving goals. Second, authority (authority) is the nature of communication or order in a formal organizational activity that is owned (received) by the participants of the organization to members of other organizations to carry out a work activity following its contribution. Third, a discipline which includes time discipline and work discipline. Fourth, the initiative is the ability to empower thinking power to complete office work while creativity is in the form of ideas to plan something related to organizational goals.

Educator performance can be assessed based on several conative aspects, namely based on the planning and implementation of learning, the implementation of the assessment and the follow-up on the results of the assessment [10]. The planning aspect is an initial activity that has a continuous impact on the student learning process. The formulation of learning objectives and the learning outcome assessment mechanism are designed at this stage. The main activity in measuring the performance of educators is in the implementation of learning. Educators are expected to be able to present material and a conducive learning atmosphere from the beginning to the end of the lesson. An assessment of student activity and a follow-up to the assessment were also carried out. The description of the activities measured in the teacher's performance can be briefly seen in the table below:

Table 2. Educator Performance

\begin{tabular}{cl}
\hline Educator Performance & \multicolumn{1}{c}{ Educator Performance Indicators } \\
\hline \multirow{3}{*}{ Learning Planning } & Formulation of learning objectives \\
& Selection and organization of study materials / subject matter \\
& Selection of media / learning tools \\
& Scenarios or learning activities \\
& Selection of learning resources \\
& Assessment of learning outcomes \\
\hline & Ability to start lessons \\
& Mastery of teaching materials (subject matter) \\
& Learning interactions / learning scenarios \\
& The attitude of the teacher in the learning process \\
& Evaluation of learning \\
& Ability to end of learning activities. \\
\hline \multirow{2}{*}{ Learning Implementation } & Provide a test or test final subject \\
& Provide an assessment of learning outcomes \\
& Check the results of student assignments or tests \\
& List of results of the assessment \\
\hline \multirow{2}{*}{ Follow-up on Assessment Results } & Manage and inform the results of the assessment \\
& Implement a program of improvement \\
& Implement an enrichment program \\
\hline
\end{tabular}




\section{Method}

\subsection{Research Method}

This study uses a quantitative approach to the type of correlational research. [11] defines quantitative research as a process of finding knowledge that uses data in the form of numbers as a tool to analyze information about what you want to know. The type of correlational research is a type of research that is intended to determine whether there is a relationship between two variables or several variables. The relationship between one variable and several other variables is expressed by the magnitude of the correlation coefficient and statistical significance. This study tested two variables, namely the competence of the Principal and the performance of the teachers.

\subsection{Participants}

The population in this study were all junior high school teachers in Makassar City. The sample is teachers at SMP Negeri 4 Makassar, teachers at SMP Negeri 6 Makassar, teachers at SMP Negeri 11 Makassar, teachers at SMP Negeri 7 Makassar, teachers at SMP Negeri 24 Makassar, and teachers at SMP Negeri 31 Makassar with 25 teachers each, so that the total participants in this study amounted to 150 people.

\subsection{Instruments}

The data collection technique in this study used a questionnaire data collection instrument with alternative answers 1 to 5 . Each questionnaire was tested first before being used in the actual research. It is intended to obtain questionnaire items per the research variables. The questionnaire consisted of competency, leadership, motivation and performance questionnaires with a reliability value of 0.894 in sequence; $0.907 ; 0.855$; and 0.968 . Principal competency items are arranged based on personality, managerial, entrepreneurial, supervisory and social aspects. Likewise, the teacher's performance variables are arranged based on the aspects of lesson planning, learning implementation, assessment implementation, and follow-up on the results of the assessment.

\subsection{Data Analysis}

The data obtained from this study were analyzed using simple regression analysis techniques to determine the results of the research hypothesis test. Regression analysis is used to examine the relationship between two or more variables, especially to trace patterns of relationships whose models are not yet fully known. This analysis also considers the coefficient of determination (R2). Data were obtained from the distribution of questionnaires given to each participant and analyzed using SPSS version 22.0.

\section{Results}

The significance test is used to determine the level of significance or linearity of the regression. The criteria are determined based on the significance value test (Sig), provided that the Sig $<0.05$. The formulation of the problem in this study was tested with regression analysis and it is known that there is an effect of the Principal's competence on the performance of teachers with this formulation:

Table 3. Result

\begin{tabular}{cl}
\hline Test Result & Score \\
\hline Score of Sig. & 0,000 \\
\hline Score of R & 0,366 \\
\hline Score of R Square & 0,134 \\
\hline
\end{tabular}

The Sig. $=0,000$ which means Sig. $<$ from significant criteria $(0.05)$. The R-value between the competency and performance variables is 0.366 , which means that the relationship between the two research variables is in a low category. The value of $\mathrm{R}$ Square or the coefficient of determination shows how good the regression model is formed by the interaction of the independent variables and the dependent variable. The $\mathrm{R}$ Square value obtained is 0.134 . So, it can be interpreted that the competence of the Principal has a contribution effect of $13.4 \%$ on the performance of teachers.

\section{Discussion}

However, the findings of this study indicate a relatively low relationship between the competence of school principals and the performance of teachers. Based on research conducted by [12], there are still inhibiting factors that allow this to happen. One of them is the mismatch between the interests and the lessons being taught so that teachers have difficulty in teaching. Moreover, there are curriculum demands that can also cause this to happen. Teachers are required to be more professional but still have not mastered the subjects being taught. Also, there are still many internal factors that occur in teaching staff, such as lack of discipline and lack of administrative control in the classroom. However, if the Principal always applies the aspect of annual supervision, these obstacles can be resolved and anticipated. Thus, the competence of the Principal affects the performance of teachers.

The results of this study found that there was an influence of the principal's competence on the performance of educators. As previously discussed, the competence of the Principal requires several aspects that 
must be fulfilled, namely aspects of personality, managerial, entrepreneurship, supervision and social. The teachers' performance is built based on several aspects of convention, such as planning and implementing learning, implementing assessments and following up on assessment results. The influence of the principal's competence on the performance of educators is built on the aspects that overshadow it.

According to [13], a person's personality affects their assessment of attitudes and behavior. In this study, several personality elements were noted that could highlight the characteristics of a school principal, namely noble character, integrity, a strong desire for self-development, being open, having self-control over problems and having talent and interest in the position of leader. The personality of the principal mentioned is very useful to be used as a role model by educators. Integrity, a strong desire for self-development, openness and interest in leadership have a role in planning student learning. At the time of implementing learning, a personality related to self-control and noble morals is needed so that problems in learning find solutions and can be used as examples of good behavior for all students and educators. That is why [14] says that the personality aspect is needed by educators when teaching.

In contrast to the personality aspect, the managerial aspect directly affects the performance of educators. School policy planning activities, development, empowerment of school resources, management of facilities to creating a conducive organizational culture are elements that directly affect the performance indicators of educators. The relationship is quite realistic because in this study the performance variables and managerial aspects of the principal's competence are variables and elements that have a greater conative content. According to [9] the ability of the principal, such as managerial competence, is one of the factors that greatly influences teacher performance in schools. The entrepreneurship aspect in this study cannot be interpreted narrowly like other definitions of entrepreneurship. The spirit of entrepreneurship in this study is built on the basis of innovation, hard work, motivation, never giving up and educational service centers. Several studies have found that innovative behavior, hard work, motivation and never give up have a significant correlation with one's performance ([15];[16]; [17]; [18]).

In practice, the Principal is not only the leader who will receive the end result of the student education process. The principal is an education supervisor who is obliged to guide and foster educators who are directly related to teaching in order to create an effective learning atmosphere [19]. The school principal carries out supervision activities to improve the performance of his educators. Supervision activities that support the improvement of the teacher's performance are the supervision program in order to increase the professionalism of educators, academic supervision with regard to learning approaches and techniques and the follow-up of the results of the educators' academic supervision itself

In the social aspect, the competence of the Principal is assessed by how the Principal is able to work together with other parties for the realization of educational goals. School participation in the community must also be shown in the form of social activities. This also tends to show the principal's sensitivity to the community. In research [20] social aspects have a positive contribution to one's performance. These forms of supervision and social activities can have a good impact on the performance of educators directly and indirectly.

The influence of the principal's competence on the performance of educators in this study is in line with what was found in [21]. Although in his research only consider managerial and supervisory functions. However, the simultaneous influence of these two functions can affect the performance of educators more. The more positive the behavior is shown by the Principal, the more positive the effect on improving the performance of educators will be. The research we describe is much broader in scope because it discusses three other aspects, namely personality, entrepreneurship and social.

With the competence of the Principal, researchers have an evidence base to prove that these competencies have a positive contribution to improving the performance of educators, especially in terms of lesson planning, implementation, assessment, and follow-up on the results of educators' assessments of students. Performance improvement in terms of planning can be in the form of formulating learning objectives, selecting and organizing learning materials, selecting learning tools, making learning scenarios, selecting learning resources and designing learning outcome assessments. Performance improvement in terms of the implementation of learning can be assessed from how the Educators' ability to open classes, mastery of material, interactions, attitudes, learning evaluation results and their ability to close the class. Educator performance can also be seen from the side of the implementation of the assessment, both when giving assignments, giving assignment assessments, providing assignment results and collecting assessment results. After carrying out these activities, performance improvement can also be seen from the follow-up after assessments are given to students. Elements of managing and informing the results of the assessment are needed in this case, likewise, in implementing improvement and enrichment programs.

Although this study found a relationship between the competence of the Principal and the performance of educators, the relationship between the two variables is still in a low category with the contribution of influence that can be said to be moderate. This shows that there are other factors in the effort to improve the performance of 
educators. According to [12] there are several things that cause the performance of educators to be hampered, such as a mismatch between interests and the lessons being taught so that educators experience difficulties in teaching. Moreover, there are curriculum demands that can also cause this to happen. Educators are required to be more professional but still have not mastered the subjects being handled. In addition, there are still many internal factors that occur in teaching staff, such as lack of discipline and lack of administrative control in the classroom. However, according to him, if the aspect of annual supervision is always applied by the principal, these obstacles can be resolved and anticipated. Thus, the competence of the principal has an effect on teaching performance.

\section{Conclusions}

This study found that there was a significant influence between the competence of the Principal and the performance of educators. Principal competency aspects that are able to influence the intensity of educator performance are personality, managerial ability, entrepreneurship, supervision and the principal's social behavior. The teacher performance can be improved from the principal's competence related to the aspects of planning and implementing learning, implementing student assessments and the follow-up of these assessments.

\section{REFERENCES}

[1] Mirsan AM. Mutu Pendidikan Rendah, PLT Kadis Makassar: Layanan Pendidikan Juga Rendah. Kabar News [Internet]. 2020 [cited 2020 Jul 6]; Available from: https://kabar.news/index.php/tags/mutu-pendidikan

[2] Srinalia S. FAKTOR-FAKTOR PENYEBAB RENDAHNYA KINERJA GURU DAN KORELASINYA TERHADAP PEMBINAAN SISWA: Studi kasus di SMAN 1 Darul Imarah Aceh Besar. JURNAL ILMIAH DIDAKTIKA: Media Ilmiah Pendidikan dan Pengajaran. 2015 Feb 1;15(2):193-207.

[3] Danim S, Khairil. Profesi Kependidikan. Bandung: Alfabeta; 2012.

[4] Amanah R. KOMPETENSI KEPALA SEKOLAH DALAM MENINGKATKAN KINERJA GURU DI SD $\begin{array}{lll}\text { MUHAMMADIYAH } & 07 & \text { RANDUDONGKAL }\end{array}$ PEMALANG TAHUN 2018 [Internet]. [Surakarta]: UNIVERSITAS MUHAMMADIYAH SURAKARTA; 2018 [cited 2020 Aug 14]. Available from: http://eprints.ums.ac.id/69199/9/NASKAH\%20PUBLIKAS I.pdf

[5] Setiawan A, Sawitri D. Pengaruh Budaya Organisasi Dan Etos Kerja Terhadap Kepuasan Kerja Berdampak Pada
Kinerja Tenaga Pendidik Di Politeknik KODIKLATAD. Arthavidya Jurnal Ilmiah Ekonomi [Internet]. 2019 [cited 2020 Aug 14];21(2). Available from: http://arthavidya.wisn uwardhana.ac.id/index.php/arthavidya/article/view/132

[6] Sudharta VA, Bafadal I, Sultoni S. KEPRIBADIAN YANG BAIK UNTUK KEEFEKTIFAN KEPEMIMPINAN KEPALA SEKOLAH. JAMP: Jurnal Administrasi dan Manajemen Pendidikan. 2018 Nov 28;1(4):440-7.

[7] Majid A. Perencanaan Pembelajaran: Mengembangkan Standar Kompetensi Guru. Bandung: Remaja Rosdakarya; 2005.

[8] Soebiantoro S. KOMPETENSI KEPALA SEKOLAH DALAM PELAKSANAAN MPBS DI SMK PEMUDA BLITAR. Cendekia: Jurnal Pendidikan dan Pembelajaran. 2014 Oct 3;8(2):121-36.

[9] El-Faradis F. Pengaruh kompetensi manajerial kepala sekolah dan motivasi kerja terhadap kinerja guru di Tarbiyatul Muallimin Al-Islamiyah (TMI) Putri Al-Amien Prenduan Sumenep Madura [Internet] [masters]. [Malang]: Universitas Islam Negeri Maulana Malik Ibrahim; 2016 [cited 2020 Aug 18]. Available from: http://etheses.uin-malang.ac.id/3965/

[10] Kementerian Pendidikan Indonesia. PERATURAN MANTERI PENDIDIKAN NASIONALNOMOR 35 TAHUN 2010 [Internet]. 2010 [cited 2020 Nov 12]. Available from: https://jatim.kemenag.go.id/file/file/peratur antentangPNS/vsef1413864091.pdf

[11] Kasiram Moh. Metodologi penelitian: Kualitatif-Kuantitatif. Malang: UIN-Maliki Press; 2010.

[12] Nurussalami N. Kompetensi Manajerial Kepala Sekolah Dalam Meningkatkan Kinerja Guru di MTsN Tungkop. CIRCUIT: Jurnal Ilmiah Pendidikan Teknik Elektro [Internet]. 2015 Sep 2 [cited 2020 Aug 18];1(1). Available from:

https://jurnal.ar-raniry.ac.id/index.php/circuit/article/view/3 06

[13] Engler B. Personality Theories. 9th Ed. Wadsworth: Cengage Learning; 2013.

[14] Fitriana S. KONSEP KEPRIBADIAN GURU MENURUT ZAKIAH DARADJAT. Muslim Heritage [Internet]. 2019 Dec 30 [cited 2020 Nov 12];4(2). Available from: http://jurnal.iainponorogo.ac.id/index.php/muslimheritage/a rticle/view/1798

[15] Mandinach EB, Cline HF. The Impact of Technological Curriculum Innovation on Teaching and Learning Activities [Internet]. Paper presented at the Annual Conference of the American Educational Research Association (San Francisco, CA, April 20-24, 1992). 1992 [cited 2020 Nov 12]. Available from: https://files.eric.ed.gov/fulltext/ED345717. pdf

[16] Raza SA. Impact Of Organizational Climate On Performance Of College Teachers In Punjab. TLC [Internet]. 2010 Oct 1 [cited 2020 Nov 12];7(10). Available from: https://clutejournals.com/index.php/TLC/article/view/155

[17] Arifin HM. The Influence of Competence, Motivation, and Organisational Culture to High School Teacher Job Satisfaction and Performance. IES. 2015 Dec 30;8(1):p38. 
[18] Culp BD. The Art of Appraiasal. London: The Rowman \& Littlefield; 2017.

[19] Ginting R. FUNGSI SUPERVISI KEPALA SEKOLAH TERHADAP KINERJA GURU. JURNAL EDUKASI NONFORMAL. 2020 Mar 4;1(2):88-93.

[20] Hakim A. Contribution of Competence Teacher
(Pedagogical, Personality, Professional Competence and Social) On the Performance of Learning. The International Journal Of Engineering And Science. 2015;4(2):12.

[21] Mas`ud M. Pengaruh Kompetensi Kepala Sekolah, Motivasi dan Kompetensi Guru terhadap Kinerja Guru serta Implikasinya pada Kompetensi Lulusan. Jurnal Ilmiah Manajemen Kontigensi. 2017 Nov 15;5(2):122-31. 